Primljeno: 27.3.2019.

Prihvaćeno: 23.7.2019.

DOI: https://doi.org/10.36506/av.62.3

\title{
Hrvoje Gržina
}

Hrvatski državni arhiv

Zagreb, Hrvatska

hgrzina@arhiv.hr

\section{DIGITALIZACIJA FOTOGRAFSKIH NEGATIVA - VAŽNOST SKRBNIČKIH ODLUKA}

UDK: 77

004

77:004

Izvorni znanstveni rad

U radu se razmatraju mogućnosti digitalizacije fotografskih negativa na različitim podlogama uz poseban naglasak na sveprisutne zablude i pogreške koje taj oblik reformatiranja prate od najranijih trenutaka do danas. U prvom su dijelu pregledno izložene osobitosti samih negativa kao objekata materijalne kulture, o kojima prije početka digitalizacije osobito valja voditi računa, a drugi dio sadržava kritički osvrt na prevodenje fotografske slike obrnutih tonskih vrijednosti u digitalni obliks ciljem poticanja na razmišljanje o materijalnosti, kontekstu nastanka i podrijetlu značenja fotografija, koji se nepažnjom ili nerazumijevanjem prirode tih objekata vrlo lako mogu nepovratno izgubiti.

Ključne riječi: digitalizacija; reformatiranje; fotografski negativi; materijalnost; kontekst; značenje; skrbničke odluke 
Digital re-presentation of photographs is a fundamental consequence of many small but meaningful decisions during the course of a digitization process that can be numbing in its routine.

Paul Conway, Building Meanings in Digital Photographs

\section{Uvod}

Snimke sa slikom u negativu kao objekti materijalne kulture u povijesti su fotografije prisutne gotovo od najranijih dana. $S$ ishodištem u otkrićima Williama Henryja Foxa Talbota iz 1830-ih godina, ubrzo su postale osnova tzv. negativ-pozitiv sustava koji je dominirao fotografijom sve do ulaska u digitalno doba. Pojam je negativa tako u početku označavao materijalne objekte iz fotografskoga aparata sa slikom obrnutih tonskih vrijednosti u odnosu na prizor iz zbilje, da bi s vremenom i razvojem tehnologije počeo poprimati i dodatna značenja, pa se tako danas koristi za sve fotografije čija je skala tonova u rasponu od tamnoga $\mathrm{k}$ svijetlomu obrnuta od stvarnosti. Tako, osim snimaka dobivenih izravno u fotoaparatu u trenutku snimanja, negativi mogu biti i objekti izrađeni iz već postojećih fotografija (internegativi ili direkt-duplikat negativi), kao i otisci obrnutoga polariteta izrađeni iz snimaka ranije generacije.

$S$ obzirom na činjenicu da većina negativa ipak nastaje u fotoaparatu u trenutku izuzimanja odabranoga kadra iz autorova okruženja, razumljivo je da kao takvi sadržavaju najveću moguću količinu informacija zabilježenih u fotografskoj slici, koja se u svakoj od narednih generacija u određenom postotku gubi. Slijedom toga, u slučajevima kada su slikovni sadržaj i moguća čitljivost detalja fotografije cilj njezina reformatiranja u digitalni oblik, opravdano je i preporučljivo postupak provesti digitalizirajući upravo snimku najranije generacije. ${ }^{1}$ Međutim, pri tom svakako valja voditi računa o činjenici da dematerijalizacija takvih objekata vrlo lako može dovesti do potpune dekontekstualizacije same snimke, kao i gubitka njezina izvornoga značenja. Zato pri digitalizaciji fotografskih negativa, osim o parametrima dobivanja digitalne slike, obvezno valja voditi računa o izvornom kontekstu same snimke i podrijetlu njezina slikovnoga značenja.

Ne bismo li navedeno pojasnili, u nadolazećim ćemo poglavljima najprije razmotriti materijalne osobitosti fotografskih negativa, a zatim i mogućnosti njihova reformatiranja u digitalni oblik. Pri tom se nećemo baviti tehničkim parametrima opreme za digitalizaciju, kao ni onima dobivene digitalne slike, nego isključivo odlukama koje skrbnik i operater uređaja moraju donijeti prije nego što skener ili senzor fotoaparata sliku predloška započnu pretvarati u binarni numerički kôd.

1 Usp. Franziska S. Frey i James M. Reilly, Digital Imaging for Photographic Collections: Foundations for Technical Standards (Rochester: Image Permanence Institute, 2006), str. 6. 


\section{Povijesni razvoj i materijalne osobitosti fotografskih negativa}

Negativima se $\mathrm{u}$ fotografiji smatraju slike sa skalom tonova $-\mathrm{u}$ rasponu od tamnoga k svijetlomu - obrnutom u odnosu na ono što prikazuju. Neke definicije uključuju i napomene kako takve slike najčešće dolaze na transparentnim podlogama kao što su film ili staklo, a druge pak dodatno ističu činjenicu da je tonska skala obrnutih vrijednosti kod negativa posve neovisna o podlozi i tehnologiji izrade. ${ }^{2} \mathrm{U}$ svakom slučaju, na negativu svijetli dijelovi dolaze kao tamni, a tamni su zabilježeni kao svijetli. Ako je riječ o negativu u boji, boje su prisutne kao komplementarne onima fotografiranoga objekta ili prizora. ${ }^{3}$ Iako se primarno vezuje uz materijalne objekte namijenjene izradi novih primjeraka sa slikom u pozitivu, taj termin označava isključivo polaritet fotografske slike koji ni na koji način ne ovisi o tehnologiji, podlozi ni procesu korištenom pri izradi fotografije, pa tako negativi osim na transparentnim podlogama mogu biti izrađeni i na reflektirajućima poput papira ili metala. U elektroničkom su okruženju zamijenjeni digitalnim datotekama koje nisu "ni negativ ni pozitiv, nego jednostavno niz znamenaka«. ${ }^{4}$ Slike takvih datoteka, po prevođenju u analognu distribuciju svjetlosti na zaslonu računala ili nekoga drugoga elektroničkog uređaja, također mogu biti u negativu. ${ }^{5}$

Najstariji danas poznati negativ datira iz 1835. godine. Riječ je o fotogeničkom crtežu već spomenutoga Williama Henryja Foxa Talbota, čija su daljnja istraživanja početkom 1840-ih dovela do uvođenja kalotipije (negativa na papiru) u standardnu fotografsku praksu. Nakon desetak godina intenzivnoga korištenja kalotipije i njezinih modifikacija, papir je postupno napuštan kao nositelj svjetloosjetljivih čestica u korist stabilnije i prozirnije podloge - stakla. Tako je staklene ploče $s$ albuminskim vezivom već 1847 . godine započeo izrađivati Claude Félix Abel Niépce de Saint-Victor, da bi uvođenjem postupka s kolodijskim vezivom (Frederick Scott Archer, 1851.) staklena podloga postala dominantni materijal za izradu fotografskih negativa. Sljedećim je tehnološkim iskorakom krajem 1870-ih kolodijsko vezivo zamijenjeno želatinskim emulzijama, koje su u upotrebi ostale sve do danas. Želatinska je emulzija, nakon stakla, kraće vrijeme nanošena i na papirnatu podlogu (tzv. Eastmanovi negativi na papiru, 1884./1885.), a početkom 20. stoljeća sve se više počinju širiti fleksibilne transparentne podloge izrađivane najprije od nitroceluloze, a zatim i acetatceluloze te poliestera, koje se koriste i danas. Uz jednobojne (crno-bijele) negative, koji su u uporabi od najranijih dana, neposredno pred Drugi svjetski rat započela je proizvodnja i negativ-filmova sa sli-

\footnotetext{
2 Usp. Hrvoje Gržina, "Utvrđivanje izvornika analognih i digitalnih fotografija," (doktorski rad, Sveučilište u Zagrebu, 2017), str. 16-17.

3 Usp. Hrvoje Gržina, Identifikacija, zaštita i čuvanje fotografija (Zagreb: Crescat, 2016), str. 6; Bertrand Lavédrine i dr., Photographs of the Past: Process and Preservation (Los Angeles: The Getty Conservation Institute, 2009), str. 8.
}

4 Gordon Baldwin i Martin Jürgens, Looking at Photographs: A Guide to Technical Terms (Los Angeles: The J. Paul Getty Museum, 2009), str. 63.

5 Usp. Gržina, “Utvrđivanje izvornika," str. 18. 
kom u boji. Taj je fotografski materijal ostao dominantan tijekom druge polovice prošloga stoljeća, sve do masovne popularizacije digitalne fotografije. ${ }^{6}$

Uz navedene, najčešće spominjane, transparentne objekte, fotografske slike u negativu koje mogu biti predmetom digitalizacije postoje i na reflektirajućim podlogama. U tom se slučaju nazivaju negativ-otiscima, a mogu nastati na više načina: umetanjem fotopapira izravno u fotoaparat na mjesto filma odnosno ploče, fotografiranjem slike u negativu ili pak umnožavanjem iz transparentnoga pozitiva, najčešće radi postizanja posebnoga nadrealnoga ili pak estetskoga dojma. ${ }^{7}$ Kao i negativ-otisci, posebnu vrstu otisaka sa slikom u negativu čine fotogrami - fotografije nastale bez uporabe fotoaparata ili fotografskoga predloška ranije generacije. Nastaju polaganjem neprozirnih ili poluprozirnih objekata na svjetloosjetljivu površinu, koje se zatim izlaže djelovanju elektromagnetskoga zračenja. Na mjestima zaklonjenima od djelovanja svjetla ostaje silueta objekta kao svijetli dio fotografske slike, a dio izložen svjetlu tamni. Ako su na površinu položeni poluprozirni objekti, papir tamni sukladno količini primljenoga zračenja. ${ }^{8}$

Osim spomenutih objekata prve generacije, negativi mogu biti i izvedeni fotografski oblici. Tako se negativ izrađen iz transparentnoga pozitiva (dijapozitiva), koji je namijenjen daljnjoj izradi slika u pozitivu, naziva internegativ ili posredni negativ, a onaj čija je namjena izrada novih pozitiva, a izrađen je izravno iz negativa ranije generacije (bez posredovanja), naziva se izravnim duplikatnegativom (direktnim duplikatom). ${ }^{9}$ U slučaju da je već postojeći fotografski otisak iznova fotografiran kako bi ga se dalje moglo reproducirati, rezultat s fotografskom slikom u negativu naziva se negativ-kopijom. Separacijski su pak negativi u kolor-fotografiji oni koji sadržavaju informacije o samo jednoj od primarnih boja konačne slike, a izrađeni su kroz crveni, zeleni i plavi separacijski filtar. ${ }^{10}$

U današnje se vrijeme često koristi i termin digitalni negativ, koji može označavati neprocesuirane podatke dobivene izravno u senzoru digitalnoga fotoaparata (osobito DNG format tvrtke Adobe(C) ili pak materijalne objekte dobivene ispisivanjem digitalnih slikovnih datoteka na transparentni materijal radi izrade daljnjih otisaka kemijskim putem, ${ }^{11}$ no zbog same prirode tih objekata, čije je ishodište digitalni kôd, malo je vjerojatno da bi mogli biti predmetom digitalizacije.

6 Usp. Hrvoje Gržina, „Negativi u zbirkama fotografija - povijest, identifikacija, obrada i zaštita“, Arhivski vjesnik 53 (2010): str. 65-82; Gržina, Identifikacija, zaštita i čuvanje fotografija, str. 67-85.

7 Usp. Baldwin i Jürgens, Looking at Photographs, str. 63.

8 Gržina, "Utvrđivanje izvornika," str. 18. Više o različitim oblicima fotograma, kao i ostalih fotografija dobivenih bez korištenja fotoaparata, usp. Geoffrey Batchen, Emanations: The Art of Cameraless Photograph (New York: Prestel, 2016).

9 Usp. Lavédrine i dr., Photographs of the Past, str. 324.

10 Gržina, "Utvrđivanje izvornika," str. 19-20.

11 Usp. Baldwin i Jürgens, Looking at Photographs, str. 33. 


\section{Ciljevi i svrha reformatiranja fotografskih negativa u digitalni oblik}

Promjena formata fotografske slike bez bitnijega zadiranja u njezin sadržaj od najranijih se dana provodila za različite ciljeve. Snimke izvorno zabilježene na transparentnim negativima kroz povijest najčešće su reformatirane u pozitivotiske kako bi se olakšalo promatranje same slike, ${ }^{12}$ ali je $s$ vremenom i razvojem svijesti o kemijskoj i fizičkoj nestabilnosti materijala porasla i potreba za reformatiranjem radi zaštite. Tako je kroz više desetljeća osmišljenu politiku zaštite fotografskih negativa činilo njihovo kopiranje i dupliciranje - izravno ili uz pomoć međuoblika - da bi danas tu ulogu u velikoj većini institucija gotovo u potpunosti preuzela digitalizacija. ${ }^{13}$

Upravo se taj novi alat pokazao vrlo korisnim za diseminaciju slikovnoga sadržaja brojnih negativa, pa stoga ne treba čuditi prvotno oduševljenje brojnim mogućnostima digitalizacije fotografske slike obrnutih tonskih vrijednosti. Međutim, ono o čemu gotovo da se i nije vodilo računa moguće su posljedice takvoga reformatiranja na podrijetlo fotografskoga značenja snimaka. Naime, obrtanjem slike u pozitiv tijekom digitalizacije uspostavlja se poseban oblik vizualne ekvivalencije kojim ti jedinstveni fotografski oblici pretvoreni u numerički kôd bivaju pojavno izjednačeni s ostatkom snimaka u repozitoriju ili bazi podataka, brišući tako granice među generacijama i poništavajući razlike u funkcijskom kontekstu samih fotografija. Upravo se stoga postavlja pitanje je li i u kojoj mjeri spomenute dvojbe moguće otkloniti, ne bi li surogati fotografskih negativa u digitalnom okruženju što vjernije prenosili obilje informacija raspršenih u slojevima tih materijalnih objekata.

Od samoga je početka digitalizacije fotografskih negativa iznimno važna jasna vizija cilja i svrhe reformatiranja tih objekata. Najčešće se spominje digitalizacija radi zaštite i povećanja dostupnosti te vrste gradiva, kao i ona radi stvaranja novih ponuda i usluga, ${ }^{14}$ no sve nabrojeno vrlo rijetko - kad su fotografski negativi u pitanju - biva ostvareno u potpunosti. Razloga je tomu više, a najvažniji od njih možemo nazvati negiranjem negativa, odnosno inzistiranjem na pre-

\footnotetext{
12 Iako je riječ isključivo o konvenciji temeljenoj na "sukladnostima prema optičkim odnosima odslikanih objekata« - prema kojoj je i gledanje slike u negativu također moguće naučiti - fotografsku je sliku većini gledalaca "draže promatrati u pozitivu", uslijed čega se skala tonskih vrijednosti sukladna zbilji uvriježila kao način prenošenja poruke fotografskih snimaka. Usp. Winfried Nöth, Priručnik semiotike (Zagreb: Ceres, 2004), str. 497.

13 Detaljnije o reformatiranju negativa radi zaštite usp. Steven Puglia, Technical Requirements for the Duplication of B\&W Negatives (College Park, MD: National Archives and Records Administration, 2001), pristupljeno 21. rujna 2018., https://www.archives.gov/files/preservation/formats/bw-copyingspecs.pdf; Gary Albright, Duplication of Historical Negatives (Andover, MA: Northeast Document Conservation Center, 1999), pristupljeno 21. rujna 2018., https://www.nedcc.org/free-resources/preservation-leaflets/6.-reformatting/6.2-duplication-of-historical-negatives.
}

14 Usp. Hrvoje Stančić, Digitalizacija (Zagreb: Zavod za informacijske studije, 2009), str. 10-11. 
vođenju fotografske slike u pozitiv tijekom digitalizacije, čime se, olakšavajući pristup slikovnomu sadržaju, zanemaruju ili u drugi plan potiskuju materijalna forma i funkcijski kontekst objekta, a time i podrijetlo njegova značenja. ${ }^{15} \mathrm{Na}$ taj način fotografski dokumenti $s$ vlastitom poviješću nastanka bivaju svedeni na puke slike, a zbirke, fondovi i čitavi arhivi reformatirani u digitalni oblik sve više prerastaju u konglomerate tzv. stock fotografije, u kojima sve češće ključni elementi opisa postaju odrednice njihova slikovnoga značenja, a manje metapodatci o formi, kontekstu nastanka, povijesti skrbništva te mjestu i ulozi pojedine snimke unutar šire cjeline gradiva. ${ }^{16}$ Ipak, imajući na umu osobitosti takve vrste gradiva, spomenute je nedostatke moguće nadvladati i premostiti informacijski jaz između njihova ukupnoga potencijala i korisničkih očekivanja. ${ }^{17}$

Razmotrimo li pobliže danas već klasične osnove za tehničku standardizaciju digitalizacije fotografskoga gradiva Franziske Frey i Jamesa Reillyja, mnoge će stvari postati jasnije. Već na samom početku autori ističu tri primjera donošenja odluka kako digitalizirati prema predviđenom korištenju digitalnih datoteka: korištenje digitalne snimke kao vizualne reference u bazi podataka, korištenje za reproduciranje i konačno kao "zamjene" za izvornik "u smislu prostornoga i tonskoga informacijskog sadržaja ". ${ }^{18}$ Povežemo li te primjere s već spomenutim najčeśćim ciljevima digitalizacije (zaštita, povećanje dostupnosti i stvaranja novih ponuda i usluga) te ih promatramo isključivo u kontekstu digitalizacije fotografskih negativa, dolazimo do nekoliko zaključaka:

1. Legitimitet negacije negativa, odnosno obrtanja polariteta fotografske slike u postupku digitalizacije gotovo je nepostojeći ako je funkcija digitalne snimke zaštitna, poglavito stoga što u tom slučaju ne ostaje nikakav trag o izgledu samoga materijalnog objekta koji služi kao izvor digitalne slike, a brojne informacije o različitim elementima njegove forme pretvaranjem u digitalni pozitiv bivaju izbrisane. Kao jedini čimbenik zaštite ostaje potencijalno reducirana upotreba krhkoga izvornika, umjesto kojega se korisniku ustupa digitalna snimka, ali pri tom valja voditi računa o činjenici da široka dostupnost digitalne inačice može

\footnotetext{
15 Tako Freyjeva i Reilly ističu da »u većini slučajeva cilj [digitalizacije] neće predstavljati reproduciranje fizičkih karakteristika izvornika, nego reproduciranje njegove pojavnosti pri određenim uvjetima promatranja» (Frey i Reilly, Digital Imaging, str. 28). Za kritiku takvoga pristupa digitalizaciji fotografija, uz vrlo izražen skepticizam prema tom postupku u cjelini usp. Joanna Sassoon, "Photographic Meaning in the Age of Digital Reproduction," LASIE: Library Automated Systems Information Exchange 29, br. 4 (1998): str. 5-15; Joanna Sassoon, "Photographic Materiality in the Age of Digital Reproduction," u Photographs, Objects, Histories: On the Materiality of Images, ur. Elizabeth Edwards i Janice Hart (Florence, KY: Routledge, 2004), str. 196-213.

${ }^{16}$ Usp. Joan M. Schwartz, "Coming to Terms with Photographs: Descriptive Standards, Linguistic 'Othering,' and the Margins of Archivy," Archivaria 54 (2002): str. 157.

17 Usp. Jasmine E. Burns, "Digital Surrogacy and the Preservation of Photographic Archives," Art Documentation: Journal of the Art Library Society of North America 36 (2017): str. 7.

18 Frey i Reilly, Digital Imaging, str. 3-4.
} 
povećati i interes korisnika za sam izvornik, ${ }^{19}$ o čijem izgledu i dalje ne postoji odgovarajuća dokumentacija ni prava zaštitna snimka. Zaštitnu funkciju digitalna snimka može u potpunosti preuzeti isključivo izradi li se kao "zamjena" za izvornik. Taj je cilj - tvrde Freyjeva i Reilly - najveći izazov jer je definiran ne samo translacijom slikovnoga sadržaja i formatom snimke nego $i$ "vrstom emulzije, uvjetima snimanja i tehnikama procesuiranja«. ${ }^{20}$

2. Govorimo li o povećanju dostupnosti, negacija negativa je opravdana, jer su se iz fotografskih negativa vrlo često izrađivali korisnički otisci u pozitivu, putem kojih se je lakše iščitavao slikovni sadržaj snimaka, a danas tu funkciju preuzimaju digitalne snimke. Njihovo uvrštavanje u bazu podataka također olakšava pristup sadržaju snimaka, no da bi bile u potpunosti funkcionalne iziskuju "podlaganje" različitim vrstama metapodataka u kojima su sadržane informacije o sadržaju, formi i kontekstu nastanka snimke, kao i njegovu odnosu s ostalim snimkama. Imajući na umu da povećanje dostupnosti sadržaja snimke može povećati i interes korisnika za izvornik, zaštitna snimka negativa i dalje se nadaje kao nužnost. Kao iznimku valja navesti reformatiranje kemijski oštećenih negativa na kojima je fotografska slika teško čitljiva ili gotovo nečitljiva. Tako su apsolutno opravdanje reformatiranja u pozitiv-sliku pokazale studije slučajeva digitalizacije oštećenih negativa na fleksibilnim transparentnim podlogama, iz kojih je vidljivo da se prevođenje u digitalni oblik nametnulo kao optimalni način spašavanja vizualnoga sadržaja kemijski nepostojanih i nepovratno oštećenih snimaka, osobito s obzirom na činjenicu da - zbog karakterističnih i ireverzibilnih oštećenja - bilo koji oblik analognoga reformatiranja ne bi dao zadovoljavajuće rezultate. ${ }^{21}$

3. U slučaju da je cilj digitalizacije stvaranje nove ponude ili usluge, jednako kao i radi povećanja dostupnosti, reformatirani oblik sa slikom u pozitivu najčešće zadovoljava predviđenu upotrebu. Ipak, s obzirom na čest slučaj istovremenoga postojanja više fotografskih objekata različitih generacija sa slikama obaju polariteta (unutar iste ili pak različitih institucija), zadržavanje njihovih ključnih vizualnih značajka u digitalnom obliku može povoljno utjecati na virtualni prikaz transformacije fotografske slike kroz različite objekte, pružajući tako jedinstveni uvid u "prostornu i vremensku dinamiku fotografske proizvodnje«. ${ }^{22}$ Unutar tako definirane "nove ponude" postojala bi potreba za digitalnim inačicama obaju polariteta.

Iz navedenoga nedvojbeno proizlazi jasna potreba za više slikovnih datoteka istoga izvornika ne bi li spomenuti ciljevi i svrhe bili najvećim dijelom ostva-

\footnotetext{
19 Usp. Bertrand Lavédrine, Jean-Paul Gandolfo i Sibylle Monod, A Guide to the Preventive Conservation of Photograph Collections (Los Angeles: The Getty Conservation Institute, 2003), str. 189.

20 Frey i Reilly, Digital Imaging, str. 4.

${ }^{21}$ Usp. Laura Capell, "Digitization as a Preservation Method for Damaged Acetate Negatives: A Case Study," The American Archivist 73 (2010): str. 235-249; Krystyna K. Matusiak i Tamara K. Johnston, "Digitization for Preservation and Access: Restoring the Usefulness of the Nitrate Negative Collections at the American Geographical Society Library," The American Archivist 77, br. 1 (2014): str. 241-269.

22 Elizabeth Edwards, "Photographs: Material Form and the Dynamic Archive," u Photo Archives and the Photographic Memory of Art History, ur. Costanza Caraffa (Berlin: Deutscher Kunstverlag, 2011), str. 54.
} 

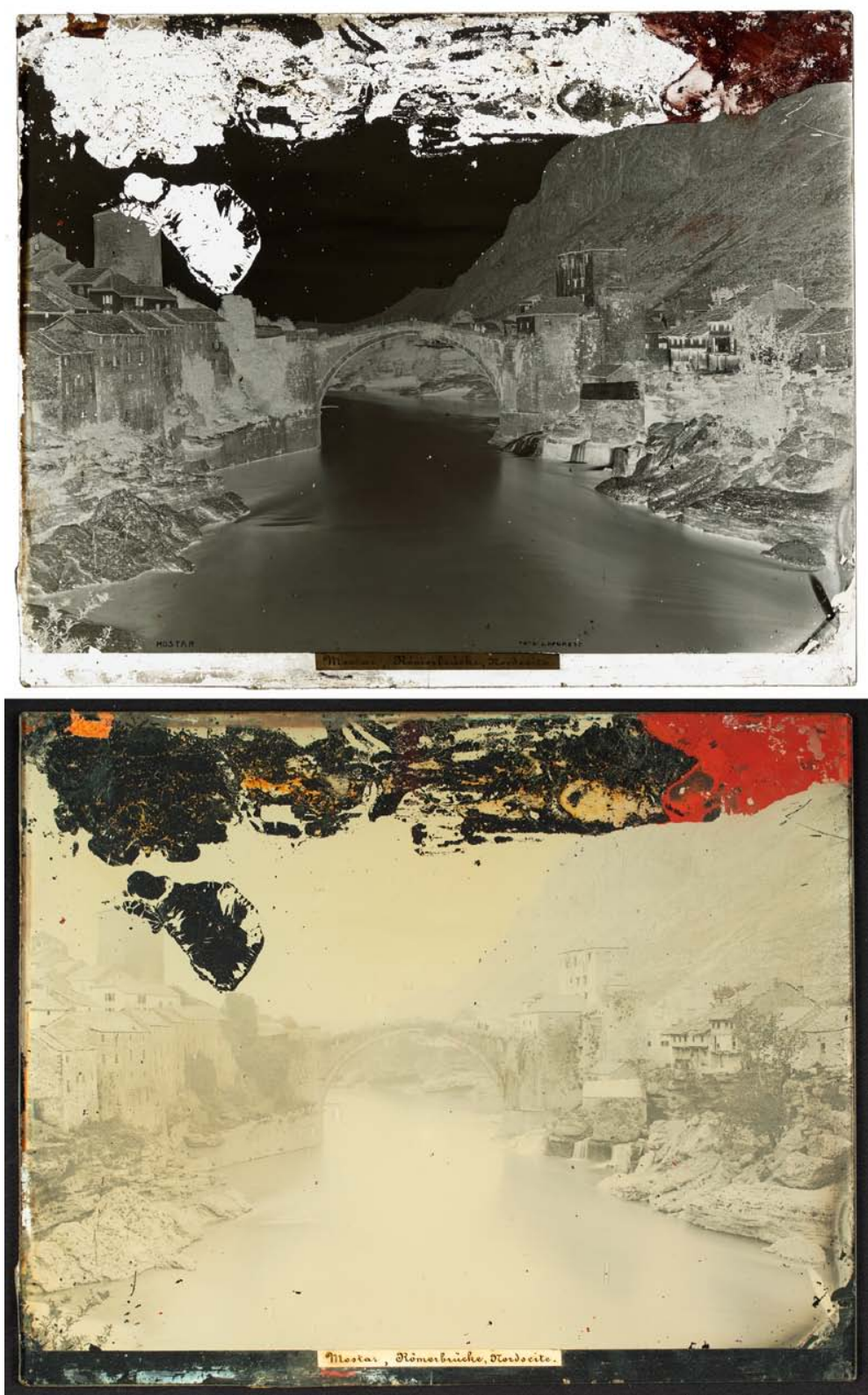

Slika 1. Modus "kao što jest« ("As IS «) - kolodijski negativ na staklenoj ploči snimljen pri prolasku svjetla kroz objekt (gore) i reflektiranome svjetlu (dolje). Franz Thiard de Laforest, Mostar, Römerbrücke, Nordseite, oko 1880., HR-HDA-1736/1.3.2. 

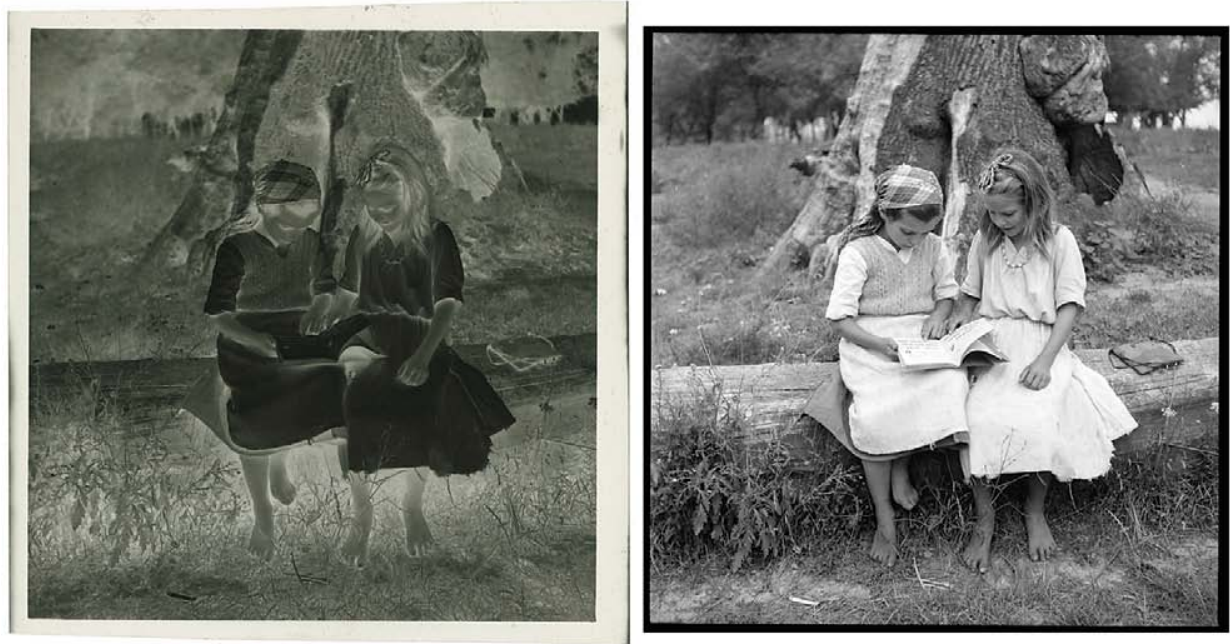

Slika 2. Modus "kako se priželjkivalo" ("As Desired") - negativ na nitroceluloznome filmu (lijevo) i digitalno generirani pozitiv (desno). Milan Pavić, Škola pod stablom, 1945., HR-HDA-1422/O-238.

rivi. Smjernice ranijega datuma za digitalizaciju transparentnih predložaka sa slikom u negativu u pravilu su savjetovale obrtanje polariteta snimke tijekom reformatiranja, ${ }^{23}$ što - kao što smo vidjeli - nikako ne može zadovoljiti zaštitnu funkciju, čak ni najkvalitetnije generiranom master-datotekom. Tako smo još prije nekoliko godina mogli pročitati da je »digitalizacija kao strategija očuvanja još uvijek predmet rasprave«. ${ }^{24}$ Nužnost master-datoteke sa slikom u negativu s vremenom je postala očitija, pa je tako ušla i u novije smjernice za digitalizaciju vizualnih materijala. U njima se preporučuje stvaranje datoteke sa slikom u negativu kao zaštitne master snimke, iz koje se zatim generira tzv. produkcijski master sa slikom u pozitivu, ${ }^{25}$ no dva odvojena skeniranja u nekim slučajevima bez sum-

${ }^{23}$ Library of Congress, Technical Standards for Digital Conversion of Text and Graphic Materials (Washington: Library of Congress, 2006), str. 26, pristupljeno 19. rujna 2018, https://memory.loc.gov/ ammem/about/techStandards.pdf; Steven Puglia, Jeffrey Reed i Erin Rhodes, Technical Guidelines for Digitizing Archival Materials for Electronic Access: Creation of Production Master Files - Raster Images (Washington: U. S. National Archives and Records Administration, 2004), str. 44, pristupljeno 19. rujna 2018, https://www.archives.gov/files/preservation/technical/guidelines.pdf.

24 Matusiak i Johnston, "Digitization for Preservation and Access," str. 241.

25 Federal Agencies Digital Guidelines Initiative, Technical Guidelines for Digitizing Cultural Heritage Materials: Creation of Raster Image Files (Washington: FADGI, 2016), str. 40-45, pristupljeno 19. rujna 2018., http://www.digitizationguidelines.gov/guidelines/FADGI\%20Federal\%20\%20Agencies\%20Digital\%20Guidelines\%20Initiative-2016\%20Final_rev1.pdf; Ian Burnett, Yukon Archives Standard for Digitizing Photographs: Creation of Raster Image Masters (Whitehorse: Government of Yukon, 2013), pristupljeno 19. rujna 2018., http://www.tc.gov.yk.ca/pdf/Yukon_Archives_Photograph_Digitization_ Standard.pdf. 


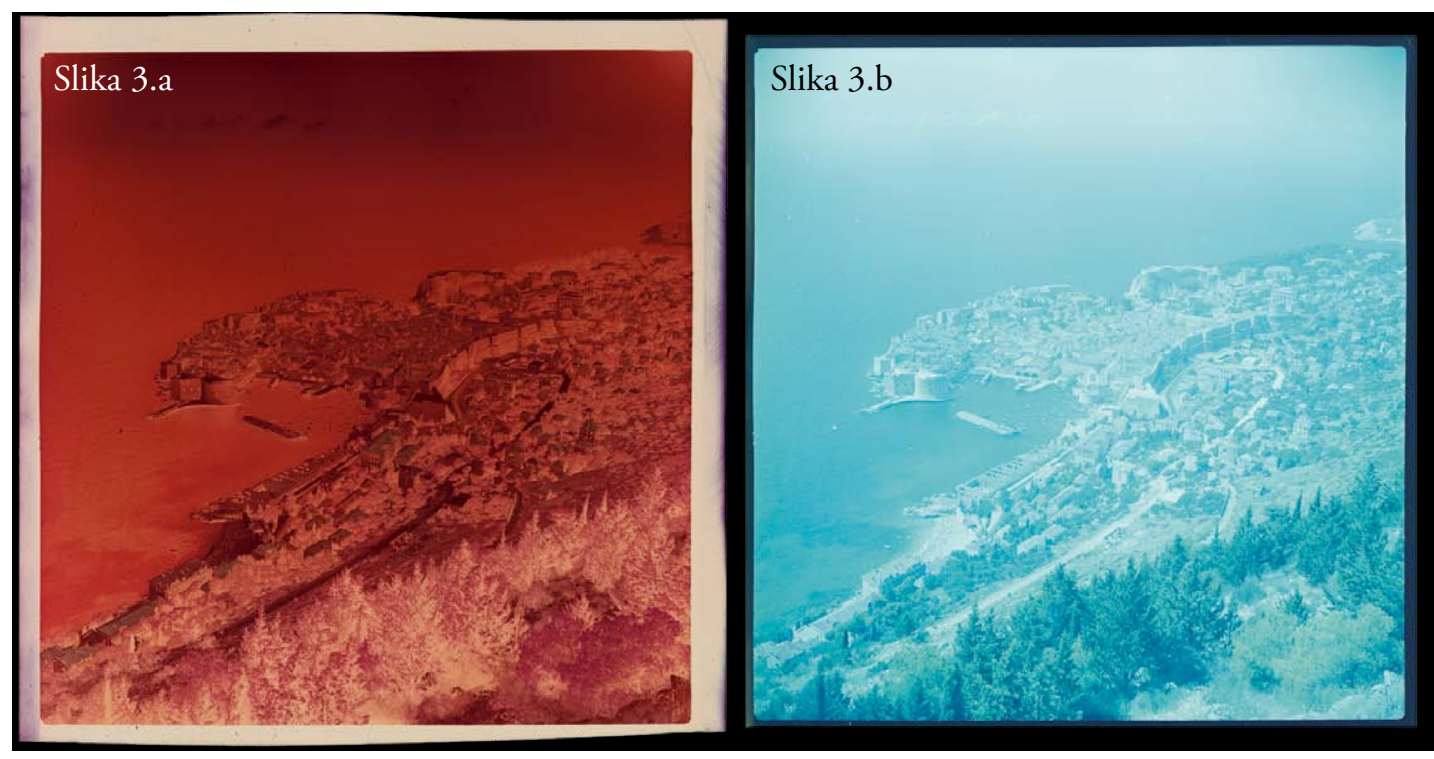

nje daju znatno bolje rezultate. Također, ponekad produkcijsku master-snimku neće biti moguće kvalitetno generirati iz zaštitne, a u nekim će slučajevima ista datoteka biti dovoljna za obje funkcije, ovisno o vrsti negativa. Stoga je glavna ideja ovoga razmatranja isticanje nužnosti kreiranja dvije master slikovne datoteke istoga predloška - jedne sa slikom u negativu koja dokumentira izgled izvornika u trenutku digitalizacije (zaštitni master) i druge sa slikom obrnutoga polariteta (produkcijski master), koji služi kao datoteka za reprodukciju i izvor svih ostalih datoteka različite namjene, uključujući tzv. poboljšanu master-datoteku i sve izvedenice (derivate). U takvom bi sustavu zaštitna i produkcijska master-datoteka, kada je god to tehnički izvedivo, nastajale kao izravni produkt digitalizacije, a poboljšani master i derivati izrađivali bi se iz produkcijskoga mastera.

\section{Modusi prevođenja negativa u digitalni oblik}

Ne bi li fotografska slika u negativu bila uspješno reformatirana, cilj i svrha njezina pretvaranja u digitalni oblik mora biti jasna od samoga početka planiranja. U tom također može pomoći model koji je razvio dvojac Frey i Reilly kao dio osnove za tehničku standardizaciju digitalizacije fotografskoga gradiva, sukladno kojemu je pretvaranje (prevođenje) fotografske slike moguće unutar četiri modusa. Slijedom prvoga, u digitalni se oblik prevodi sama slika, a u drugom je riječ o prevođenju u digitalno okruženje fotografove namjere. Treći je modus prevođenje (rekonstruiranje) izvorne pojavnosti snimke, a četvrti pak pre- 

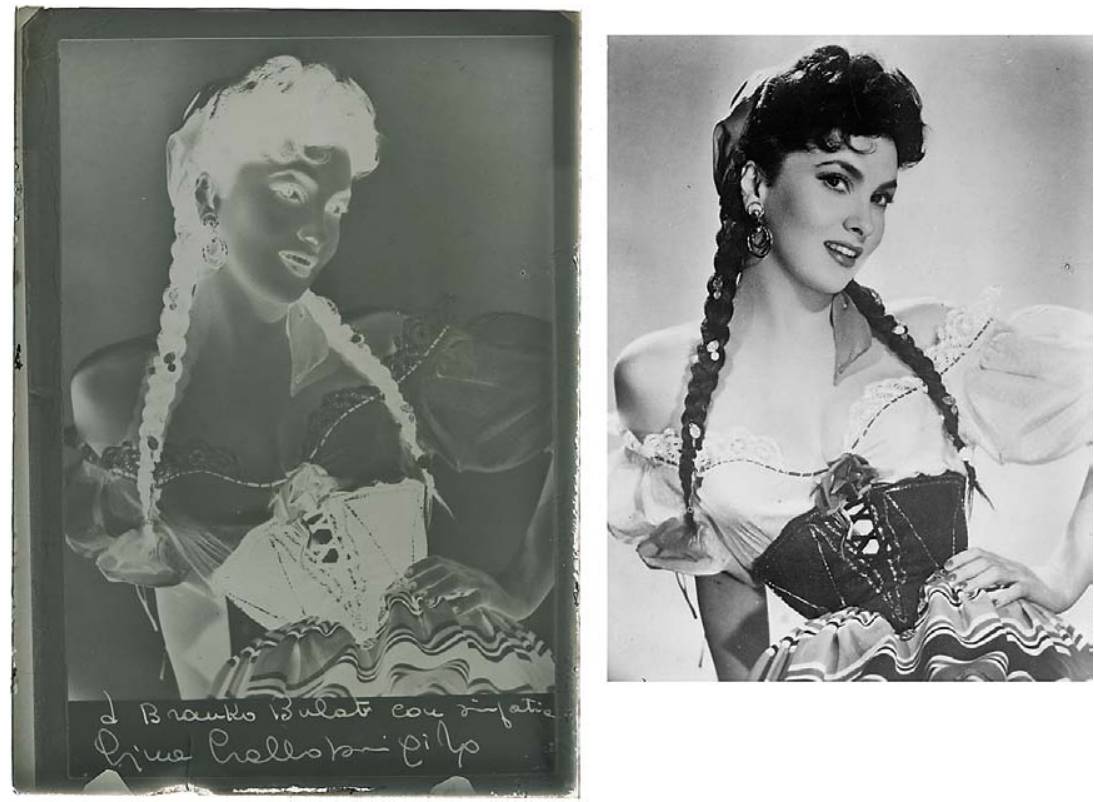

Slika 4. Modus "kao što je videno" ("As Seen") - želatinski negativ na staklenoj ploči s reprodukcijom fotografskoga otiska ranijega datuma (lijevo) i digitalno generirani pozitiv reduciran na sliku predloška (desno). Neutvrdeni autor, Gina Lollobrigida (reprodukcija), 1950-ih, HR-HDA-1211.

nom surogatu spomenuti nedostatci pokušavaju ispraviti odnosno nadomjestiti, i to pozivajući se na pretpostavku da je fotografova namjera bila snimiti i izraditi ispravnu i zadovoljavajuću snimku. ${ }^{29} \mathrm{~S}$ obzirom na to da se temelji na pretpostavci, u slučaju nepostojanja referentnoga objekta istoga autora, vrlo je teško ispravno predvidjeti namjeru osobe koja je fotografiju snimila, pa tako taj modus prije svega ovisi o vještini i vizualnoj pismenosti operatera uređaja za digitalizaciju. ${ }^{30}$ Kad govorimo o digitalizaciji fotografskih negativa, taj modus vrijedi uzeti u razmatranje tek pri izradi produkcijskoga mastera, jer onaj zaštitni mora odražavati stanje snimke u trenutku reformatiranja sa svim vidljivim tragovima povijesti korištenja i skrbništva. Tijekom digitalizacije s uključenim obrtanjem polariteta moguće je nadomjestiti postojeće nedostatke kako bi optimalna interpretacija snimke bila dostupna korisniku (Slika 2). Conway u svojem komentaru toga modusa - nazivajući ga As Desired, odnosno "kako se priželjkivalo" - izvodi ispravan zaključak o opravdanosti obrtanja polariteta u slučaju digitalizacije negativa radi daljnjega korištenja, ali ga temelji na pogrešno postavljenoj premisi potenci-

\footnotetext{
29 Frey i Reilly, Digital Imaging, str. 29.

30 Usp. FADGI, Technical Guidelines, str. 41.
} 
jalne fotografove namjere da njegova slika bude gledana kao otisak u pozitivu. ${ }^{31}$ Premisa je pogrešna stoga što je otisak u pozitivu druga generacija iste fotografske slike, kojoj nužno prethodi snimka sa slikom u negativu, pa je stoga fotografova namjera prije svega morala biti snimanje negativa, ali ne nužno i izrada otiska. Da je fotografova namjera bila da slika odmah bude dostupna kao pozitiv, po svoj bi se prilici poslužio drukčijim materijalom (dijapozitivom ili nekim od izravnih pozitiva) kojim bi istom po snimanju dobio pozitiv-sliku.

3. Pokušaj rekonstrukcije izvorne pojavnosti fotografije traži izuzetno visoku razinu vizualne pismenosti te poznavanje ključnih osobitosti brojnih fotografskih procesa ne bi li se moglo naknadno intervenirati u oštećenu snimku pokušavajući joj vratiti zamišljeni prvobitni izgled, zadržavajući pritom njezine esencijalne značajke. Iz toga razloga Conway taj modus tumači kao As WAS, odnosno "kako je bilo" ${ }^{32}$ Kod digitalizacije negativa moguće ga je primijeniti pri generiranju produkcijskoga iz zaštitnoga mastera ili pak kod izvođenja poboljšanoga mastera iz produkcijske datoteke, pri čemu se, primjerice, ispravljaju blijeđenje i pomak boje kod snimaka zabilježenih na kolor-negativima (Slika 3). ${ }^{33}$

4. Pokušaj prevođenja u digitalni oblik izvornoga prizora - Conwayjev As Seen ili "kao što je viđeno" ${ }^{34}$ - moguće je uzeti u obzir isključivo kod digitalizacije reprosnimaka, odnosno u slučaju kojim se bavimo, negativ-kopija. Kako je riječ o digitalizaciji negativa na čijim su slikama zabilježene fotografije ranijega datuma, tim se modusom u digitalnoj inačici zadržava samo slika predloška zabilježenoga na negativu, a ostatak fotografske slike ostaje izvan područja interesa odnosno "biva izuzet". ${ }^{35}$ Upravo se zato ni u kojem slučaju ne preporučuje, primarno zbog toga što pokušajem vizualnoga izjednačavanja sa snimkom ranije generacije poništava sve elemente materijalnosti, konteksta i značenja, što ustanova ili osoba koja o fotografskom gradivu skrbi nikako ne bi smjela dopustiti. ${ }^{36}$ Ipak, u slučaju potrebe i ako je produkcijski master izveden na zadovoljavajući način, svaki krajnji korisnik vraćanje izvornoga prizora ipak može pokušati primijeniti za specifičnu namjenu odbacivanjem spomenutoga "viška" naknadnom obradom na računalu (Slika 4).

Pokušamo li sagledati mogućnosti digitalizacije negativa u svjetlu spomenutih modusa, jasno je vidljivo da je stvaranje digitalne zbirke koja bi odgovarala svim mogućim zahtjevima "kompleksan i mnogostran postupak u kojem je na svakom koraku na djelu interakcija tehnoloških alata, značajka predložaka i neri-

\footnotetext{
Conway, "Building Meaning," str. 7.

32 Conway, "Building Meaning," str. 7.

33 Usp. FADGI, Technical Guidelines, str. 41-42.

34 Conway, "Building Meaning," str. 8.

35 Frey i Reilly, Digital Imaging, str. 29.

36 Usp. Conway, "Building Meaning," str. 7-8.
} 
jetko nejasno izraženih ciljeva i svrhe« ${ }^{37}$ Ipak, slijedeći istaknuto u ovom razmatranju i držeći se tehničkih parametara spomenutih u smjernicama, izradom dviju različitih master-datoteka i kvalitetno definiranim skupovima metapodataka moguće je odgovoriti na dobar dio zahtjeva koji se u posljednje vrijeme postavljaju pred skrbnike fotografskoga gradiva.

\section{Materijalni objekti u digitalno doba}

Fotografski su negativi, koje smo ovdje razmatrali - baš kao i ostale fotografije - prije svega materijalni objekti. Prevođenje njihovih ključnih vizualnih značajka u digitalno okruženje predstavlja, pokazalo se, popriličan izazov. Zato vrijedi istaknuti nekoliko bitnih svojstava svake od skupina negativa koje bi trebale biti vidljive na dobro izrađenome master-setu digitalnih surogata, kako bi se što je moguće uspješnije pokušao premostiti jaz između materijalnoga i virtualnoga.

1. Za negative na papiru zaštitnu se master-datoteku preporučuje izraditi na plošnom skeneru ili korištenjem fotoaparata uz prosvjetljavanje kroz negativ, zadržavajući polaritet predloška i obvezno u boji, kako bi na snimkama ostale zabilježene ključne osobitosti materijalnoga objekta koji se prevodi u digitalni oblik (boja, retuš, inskripcije i dr.). ${ }^{38}$ Zaštitna master-snimka mora obuhvaćati čitav predložak, pri čemu granice između objekta i podloge moraju biti jasno vidljive. Dodatni zaštitni master može se izraditi pri reflektiranom svjetlu, ako postoji potreba za naglašavanjem određenih elemenata forme (papirnata maska, ljepljive trake i dr.). Produkcijski master preporučuje se izraditi novim skeniranjem $s$ uključenim obrtanjem polariteta i u sivoj skali, podešavajući snimku da izgleda zadovoljavajuće za pregled na zaslonu računala i daljnje korištenje. Moguće ju je izvesti i iz zaštitnoga mastera obrtanjem polariteta te prebacivanjem u sivu skalu, no u tom slučaju bit će potrebno dodatno podešavanje tonova i kontrasta da bi se dobila zadovoljavajuća snimka u pozitivu. Preporučljivo je da datoteke sa slikom u pozitivu budu u sivoj skali zato što je riječ o jednobojnom fotografskom predlošku - slika je karakteristično smeđe ili žuto-smeđe boje ${ }^{39}$ čijim bi se obrtanjem u pozitiv dobila komplementarna skala svijetloplavih ili svijetloljubičastih tonova, posve atipična za razdoblje i duh vremena u kojem su snimke nastale. Pri opisivanju svakako valja uključiti napomenu da je riječ o digitalnom pozitivu izvedenom iz izvornoga negativa na papiru, uz što je moguće precizniju determinaciju fotografskoga procesa.

37 Usp. Conway, "Building Meaning," str. 7-8.

38 Za primjere kvalitetno izrađenih zaštitnih snimaka negativa na papiru usp. Lavédrine i dr., Photographs of the Past, str. 225-230; Anne Cartier-Bresson, Le vocabulaire technique de la photographie (Paris: Marval, 2008), str. 44, 72-74; Maria Fernanda Valverde, Photographic Negatives: Nature and Evolution of Processes (Rochester: George Eastman House, 2005), str. 5; Karen Hellman, Real/Ideal: Photography in Mid-Nineteenth-Century France (Los Angeles: The J. Paul Getty Museum, 2016), str. 59-86.

39 Gržina, "Negativi u zbirkama fotografija," str. 66. 
2. Negative na staklenim pločama u digitalni se oblik preporučuje pretvarati na sličan način kao i njihove srodnike na papirnatoj podlozi, upotrebom plošnoga skenera ili fotoaparata uz prolazak svjetla kroz negativ. Zaštitni master valja svakako izraditi u boji uz zadržavanje negativ-polariteta kako bi na digitalnoj snimci ostale zabilježene ključne osobitosti materijalnoga objekta (boja, zaštitni premaz, retuš, inskripcije i dr.).$^{40}$ Zaštitna master-snimka mora obuhvaćati čitav predložak, pri čemu granice između objekta i podloge moraju biti jasno vidljive. Dodatni zaštitni master može se izraditi pri reflektiranom svjetlu, ako postoji potreba za naglašavanjem određenih elemenata forme (srebrni odsjaj, papirnata maska, ljepljive trake i dr.). Produkcijski master preporučuje se izraditi novim skeniranjem $s$ uključenim obrtanjem polariteta i u sivoj skali, podešavajući snimku da izgleda zadovoljavajuće za gledanje i daljnje korištenje. Moguće ju je izvesti i iz zaštitnoga mastera obrtanjem polariteta te prebacivanjem u sivu skalu, no u tom slučaju bit će potrebno dodatno podešavanje tonova i kontrasta kako bi se dobila zadovoljavajuća snimka u pozitivu. Preporučljivo je da datoteke sa slikom u pozitivu budu u sivoj skali stoga što je također riječ o jednobojnom fotografskom materijalu čija je fotografska slika - u slučaju da je riječ o albuminskom ili kolodijskom vezivu - najčešće krem ili sivosmeđe boje, ${ }^{41}$ pa bi se njezinim obrtanjem u pozitiv dobila komplementarna skala svijetloplavih i svijetloljubičastih tonova, posve atipična za razdoblje i duh vremena u kojem su snimke nastale. Taj je dio posla razmjeno jednostavniji kod neoštećenih želatinskih staklenih negativa, koji su neutralne sivocrne boje, pa samo obrtanje polariteta nije tako drastično različito od predviđenoga rezultata, a za one oštećene, s izraženijim žutilom svijetlih dijelova slike ili pak srebrnim odsjajem u tamnim dijelovima ostaje preporućljivo digitalni pozitiv izraditi u sivoj skali. Pri opisivanju također obavezno treba uključiti napomenu da je riječ o digitalnom pozitivu izvedenom iz izvornoga negativa na staklu uz dodatno određenje fotografskoga procesa.

3. Negative na filmu u digitalni oblik moguće je prevesti na više načina, ovisno o veličini (formatu) predloška, načinu njegove prezentacije (plan-film, filmski svitak, isječci ili pojedinačno rezane snimke) te boji. Tako je, osim upotrebom plošnoga skenera ili fotoaparata, tu skupinu negativa moguće digitalizirati i na posebnim uređajima namijenjenima digitalizaciji fleksibilnih transparentnih predložaka. Oni u pravilu daju digitalnu sliku optimalne korisničke kvalitete, no zbog načina umetanja predložaka u sam skener, nije ih moguće koristiti za izradu zaštitnih mastera. ${ }^{42}$ Zaštitni master svakako je potrebno izraditi u boji uz zadrža-

\footnotetext{
40 Za primjere kvalitetno izrađenih zaštitnih snimaka negativa na staklenim podlogama usp. Lavédrine i dr., Photographs of the Past, str. 235-250; Cartier-Bresson, Le vocabulaire technique, str. 47-52, 70-71; Valverde, Photographic Negatives, str. 9, 14; Sylvie Aubenas, Gustave Le Gray 1820-1884 (Los Angeles: The J. Paul Getty Museum, 2002), str. 286-295.

41 Gržina, "Negativi u zbirkama fotografija," str. 71.

42 Uporaba rotacionih skenera nikako se ne preporučuje zbog posebnoga načina fiksiranja predloška na zakrivljenu površinu bubnja koji može dovesti do njegova oštećenja (usp. FADGI, Technical Guidelines,
} 
vanje negativ-polariteta kako bi na digitalnoj snimci ostale zabilježene ključne osobitosti materijalnoga objekta kao što su boja, eventualni retuš (rijetko), inskripcije, perforacija, urezani kôd, mjesto u nizu ako je riječ o isječku ili svitku i dr. ${ }^{43}$ Zaštitna master-snimka mora obuhvaćati čitav predložak, pri čemu granice između objekta i podloge moraju biti jasno vidljive, pa tako, u slučaju kada je film u svitku izrezan u dijelove, valja zabilježiti čitav isječak. Dodatni zaštitni master može se izraditi pri reflektiranom svjetlu, ako postoji potreba za naglašavanjem određenih elemenata forme poput srebrnoga odsjaja, papirnate maske, ljepljivih traka i dr., koji su kod te skupine negativa dosta rijetki, tek ponekad vidljivi na plan-filmovima većega formata. Produkcijski master preporučuje se izraditi novim skeniranjem $s$ uključenim obrtanjem polariteta i u sivoj skali za crno-bijele filmove, odnosno u boji za kolor-filmove, podešavajući snimku da izgleda zadovoljavajuće za gledanje i daljnje korištenje. Izrada produkcijskoga mastera na namjenskom skeneru za filmove svakako daje optimalan rezultat $\mathrm{i}$ znatno kvalitetniju sliku, ali ju je moguće generirati i iz zaštitnoga mastera obrtanjem polariteta te prebacivanjem u sivu skalu (u slučaju da je predložak crnobijeli film). U tom slučaju svakako će biti potrebno dodatno podešavanje boje, tonova i kontrasta kako bi se dobila zadovoljavajuća snimka u pozitivu. Bez obzira na korišteni uređaj, preporučljivo je da datoteke sa slikom u pozitivu iz crno-bijelih negativa budu u sivoj skali jer je riječ o jednobojnom fotografskom materijalu $s$ fotografskom slikom neutralne sivo-crne boje, a u slučaju negativa u boji ključnu osobitost čitave skupine svakako treba zadržati. Pri opisivanju također valja obvezno uključiti napomenu da je riječ o digitalnom pozitivu izvedenom iz izvornoga negativa na filmu uz dodatno određenje fotografskoga procesa.

4. Fotografije na reflektirajućim podlogama sa slikom u negativu poput negativ-otisaka ili fotograma u digitalni je oblik moguće prevesti upotrebom plošnoga skenera ili fotoaparata pri reflektiranom svjetlu. Za tu skupinu objekata ista će slikovna datoteka imati ulogu zaštitnoga i produkcijskoga mastera jer nema potrebe za obrtanjem polariteta.

5. Negativ-kopije, internegativi, duplikat-negativi i separacijski negativi digitaliziraju se jednako kao i izvornici (točke 1-3), ovisno o podlozi i vrsti fotografskoga materijala.

str. 53; Stančić, Digitalizacija, str. 37-38). Korištenje skenerima za filmove pak iziskuje postavljanje predloška unutar namjenski izrađenih držača (tzv. maske) koji prekrivaju dio predloška i u pravilu su dizajnirani kako bi svjetlo prolazilo isključivo kroz dio filma na kojem je zabilježena fotografska slika (usp. FADGI, Technical Guidelines, str. 53).

43 Za primjere kvalitetno izrađenih zaštitnih snimaka negativa na filmu usp. Gržina, Identifikacija, str. 77-82; Lavédrine i dr., Photographs of the Past, str. 258; Cartier-Bresson, Le vocabulaire technique, str. 61-69; Valverde, Photographic Negatives, str. 19, 24, 29. 


\section{Zaključak}

Digitalizacija fotografskih negativa višeslojan je i zahtjevan skup različitih odluka i radnja koje pojedinac ili institucija moraju donijeti i provesti kako bi rezultat bio što je više moguće zadovoljavajući. S obzirom na to da se digitalizacijom u pravilu pokušava odgovoriti na više potreba, u rasponu od zaštite gradiva do njegove potencijalne virtualne prezentacije, jasno definirane "male, ali važne odluke" istaknute u motu na početku rada nužan su preduvjet uspješnoga reformatiranja te skupine fotografija u digitalni oblik. $U$ ovom je radu stoga istaknuta važnost zaštitne master slikovne datoteke koja dokumentira izgled fotografskih negativa kao objekata materijalne kulture u trenutku digitalizacije, sa svim tragovima korištenja i skrbništva, te kao takva daje jedinstvene podatke o materijalnoj formi i funkcijskom kontekstu samih snimaka, a time i njihovu značenju. Pokazalo se da je iz kvalitetne zaštitne master-datoteke u nekim slučajevima moguće generirati i produkcijski master, iako se optimalni rezultati u pravilu postižu odvojenim skeniranjem, osobito ako je riječ o negativima na fleksibilnim podlogama za koje postoje namjenski uređaji koji njihovu fotografsku sliku prevode u digitalni oblik.

S obzirom na međusobne različitosti samih fotografskih predložaka iz skupine negativa, osobit je naglasak stavljen na ciljeve i funkcije njihove digitalizacije te na izbjegavanje opasnosti koju smo ovdje nazvali negacijom negativaprevođenja u digitalni oblik bez dokumentiranja pojavnosti samoga materijalnog objekta. Jednako su tako istaknuti i modusi prevođenja negativa u digitalno okruženje, o kojima valja voditi računa pri izradi zaštitnoga i produkcijskoga mastera, kao i generiranju ostalih izvedenih datoteka. Pored svega navedenoga, jednako je važno i "opremanje" svake od digitalnih slikovnih datoteka odgovarajućim setovima metapodataka ne bi li vječiti jaz između materijalnoga i virtualnoga po dovršenom postupku digitalizacije bio što je moguće manji, a većina informacija zabilježenih u slojevima analognih fotografskih negativa prevedena u digitalni oblik zadržavajući podatke o formi, sadržaju i funkcijskom kontekstu, a time i podrijetlu njihova značenja.

\section{POPIS IZVORA}

\section{Arhivsko gradivo}

\section{Hrvatski državni arhiv} armije.

HR-HDA-1211. Zapovjedništvo 5. vojne oblasti Jugoslavenske narodne

HR-HDA-1422. Fond fotografija Agencije za fotodokumentaciju (AGEFOTO).

HR-HDA-1736. Zbirka fotografija obitelji Laforest. 


\section{Literatura}

Albright, Gary. Duplication of Historical Negatives. Andover, MA: Northeast Document Conservation Center, 1999. Pristupljeno 21. rujna 2018., https:// www.nedcc.org/free-resources/preservation-leaflets/6.-reformatting/6.2-duplication-of-historical-negatives.

Aubenas, Sylvie. Gustave Le Gray 1820-1884. Los Angeles: The J. Paul Getty Museum, 2002.

Baldwin, Gordon, Martin Jürgens. Looking at Photographs: A Guide to Technical Terms. Los Angeles: The J. Paul Getty Museum, 2009.

Batchen, Geoffrey. Emanations: The Art of Cameraless Photograph. New York: Prestel, 2016.

Burnett, Ian. Yukon Archives Standard for Digitizing Photographs: Creation of Raster Image Masters. Whitehorse, Yukon: Government of Yukon, 2013. Pristupljeno 19. rujna 2018., http://www.tc.gov.yk.ca/pdf/Yukon_Archives_Photograph_Digitization_Standard.pdf.

Burns, Jasmine E. "Digital Surrogacy and the Preservation of Photographic Archives." Art Documentation: Journal of the Art Library Society of North America 36 (2017): str. 1-8.

Capell, Laura. "Digitization as a Preservation Method for Damaged Acetate Negatives: A Case Study." The American Archivist 73 (2010): str. 235-249.

Cartier-Bresson, Anne, ur. Le vocabulaire technique de la photographie. Paris: Marval, 2008.

Conway, Paul. "Building Meaning in Digitized Photographs." Journal of the Chicago Colloquium on Digital Humanities and Computer Science 1 (2009). Pristupljeno 20. rujna 2018., https://knowledge.uchicago.edu/handle/11417/1006.

Edwards, Elizabeth. "Photographs: Material Form and the Dynamic Archive." U Photo Archives and the Photographic Memory of Art History, ur. Costanza Caraffa, str. 47-56. Berlin: Deutscher Kunstverlag, 2011.

Federal Agencies Digital Guidelines Initiative. Technical Guidelines for Digitizing Cultural Heritage Materials: Creation of Raster Image Files. Washington, DC: FADGI, 2016. Pristupljeno 19. rujna 2018. http://www.digitizationguidelines.gov/guidelines/FADGI\%20Federal\%20\%20Agencies\%20Digital\% 20Guidelines\%20Initiative-2016\%20Final_rev1.pdf.

Frey, Franziska S., James M. Reilly. Digital Imaging for Photographic Collections: Foundations for Technical Standards. Rochester: Image Permanence Institute, 2006. 
Gržina, Hrvoje. "Negativi u zbirkama fotografija - povijest, identifikacija, obrada i zaštita." Arhivski vjesnik 53 (2010): str. 63-84.

Gržina, Hrvoje. "Utvrđivanje izvornika analognih i digitalnih fotografija." Doktorski rad, Sveučilište u Zagrebu, 2017. cat, 2016.

Gržina, Hrvoje. Identifikacija, zaštita i čuvanje fotografija. Zagreb: Cres-

Hellman, Karen, ur. Real/Ideal: Photography in Mid-Nineteenth-Century France. Los Angeles: J. Paul Getty Museum, 2016.

Lavédrine, Bertrand, Jean-Paul Gandolfo, John McElhone, Sibylle Monod. Photographs of the Past: Process and Preservation. Los Angeles: The Getty Conservation Institute, 2009.

Lavédrine, Bertrand, Jean-Paul Gandolfo, Sibylle Monod. A Guide to the Preventive Conservation of Photograph Collections. Los Angeles: The Getty Conservation Institute, 2003.

Library of Congress. Technical Standards for Digital Conversion of Text and Graphic Materials. Washington: Library of Congress, 2006. Pristupljeno 19. rujna 2018., https://memory.loc.gov/ammem/about/techStandards.pdf.

Matusiak, Krystyna K., Tamara K. Johnston. "Digitization for Preservation and Access: Restoring the Usefulness of the Nitrate Negative Collections at the American Geographical Society Library." The American Archivist 77, br. 1 (2014): str. 241-269.

Nöth, Winfried. Priručnik semiotike. Zagreb: Ceres, 2004.

Puglia, Steven, Jeffrey Reed, Erin Rhodes. Technical Guidelines for Digitizing Archival Materials for Electronic Access: Creation of Production Master Files Raster Images. Washington, DC: U. S. National Archives and Records Administration (NARA), 2004. Pristupljeno 19. rujna 2018., https://www.archives. gov/files/preservation/technical/guidelines.pdf.

Puglia, Steven. Technical Requirements for the Duplication of B\&W Negatives. College Park, MD: National Archives and Records Administration, 2001. Pristupljeno 21. rujna 2018., https://www.archives.gov/files/preservation/formats/bw-copying-specs.pdf.

Sassoon, Joanna. "Photographic Materiality in the Age of Digital Reproduction." U Photographs, Objects, Histories: On the Materiality of Images, ur. Elizabeth Edwards i Janice Hart, str. 196-213. Florence, KY: Routledge, 2004.

Sassoon, Joanna. "Photographic Meaning in the Age of Digital Reproduction." LASIE: Library Automated Systems Information Exchange 29, br. 4 (1998): str. 5-15. 
Schwartz, Joan M. "Coming to Terms with Photographs: Descriptive Standards, Linguistic 'Othering,' and the Margins of Archivy." Archivaria 54 (2002): str. 142-171. 2009.

Stančić, Hrvoje. Digitalizacija. Zagreb: Zavod za informacijske studije,

Valverde, Maria Fernanda. Photographic Negatives: Nature and Evolution of Processes. Rochester: George Eastman House, 2005.

Summary

\section{DIGITIZATION OF PHOTOGRAPHIC NEGATIVES - THE IMPORTANCE OF CUSTODIAL DECISIONS}

The article considers digitization possibilities of photographic negatives on various supports with the special emphasis on the ubiquitous errors and mistakes that accompany that kind of reformatting from the earliest moments until today. The first part clearly explains the particularities of negatives as objects of material culture that have to especially be taken into account before digitization begins. By using polarity as a property of the photographic image, various types of negatives were elaborated, according to their supports photographic processes and function. Hence, for the first time, together with the often mentioned negatives on paper, glass and plastic, which usually have "original« as their added adjective, other photographic forms with an image in negative are also included, such as photograms, negative-prints, negative-copies, internegatives or separation negatives that can also be objects of digitization. The second part of the text contains a critical review of transferring a photographic image of the reversed tonal value in the digitized form with the aim of encouraging the thinking about materiality, context of inception and the origin of photographic meaning which can become irreversibly lost due to carelessness or non-comprehension of the nature of these objects. By reviewing various digitization guidelines, the need is emphasized for a clearly defined point and aims of reformatting negatives into a digitized form according to the expected usage of digitized files i.e. depending if digitized images will be used as visual references in a database, for reproducing or as a "replacement " for an original in the sense of spatial and tonal informational content. The appearance of the negation of the negative is emphasized as the primal danger of the unclearly defined aim and purpose, which in the large number of cases is manifested by the polarity change during digitization, after which there are no remaining documentation about the real outlook of the template. The possible goals and aims of digitization are next considered within four modes 
of transferring templates into digital form - transferring the template's image, transferring photographer's intention, transferring (reconstructing) the original manifestation of the digitized image and transferring the original sight - from which the guidelines for their successful reformatting are separated. The importance of creating two master files is emphasized - a protective and a production one - of which the former documents the appearance of the template with all elements of form and negative polarity, while the latter by revolving the software image into a positive would fulfil the users' and other possible functions. Besides this, the importance of "underlaying" each of the acquired digitized pictorial images with appropriate sets of metadata is emphasized several times, in order to bridge the eternal gap between the material and the virtual as much as possible once the digitization process is complete, and for the majority of information registered in layers of analogue photographic negatives to be transferred into the digitized formation, while keeping the data on form, content and functional context and with this also on the origin of their meaning.

Keywords: digitization; reformatting; photographic negatives; materiality; context; meaning; custodian's decisions 